\title{
IMPLEMENTASI KEBIJAKAN PENATAAN INDEKOS ATAU RUMAH KONTRAKAN DI KOTA SUKABUMI
}

\author{
${ }^{1}$ Dhea Juniar, ${ }^{2}$ Ike Rachmawati, \& ${ }^{3}$ Dine Meigawati \\ ${ }^{1}$ Universitas Muhammadiyah Sukabumi \\ Email:dheajuniar0@gmail.com \\ ${ }^{2}$ Universitas Muhammadiyah Sukabumi \\ Email: ike_rachmawatil@yahoo.com \\ ${ }^{3}$ Universitas Muhammadiyah Sukabumi \\ Email: dinemeigawati@gmail.com
}

\begin{abstract}
Abstrak
Penelitian bertujuan untuk mengetahui implemetasi kebijakan penataan indekos atau rumah kontrakan di Kota Sukabumi, serta faktor-faktor yang mempegaruhinya. Peneliti menggunakan teori implementasi kebijakan publik menurut van Metter \& van Horn. Penelitian ini menggunakan metode kualitatif deskriptif dengan pengumpulan data melalui teknik observasi, wawancara, dokumentasi, dan studi kepustakaan. Implementasi kebijakan penataan indekos atau rumah kontrakan di Kota Sukabumi sudah berjalan dengan baik jika dilihat dari sisi sumber daya, karakteristik agen pelaksana, dan kecenderungan/disposisi para pelaksana. Namun dari sisi ukuran dan tujuan kebijakan, komunikasi antar organisasi dan aktivitas pelaksana serta lingkungan ekonomi, sosial dan politik belum berjalan dengan baik. Hal tersebutlah yang menghambat keberhasilan dari pelaksanaan implementasi kebijakan tentang penataan indekos atau rumah kontrakan di Kota Sukabumi.
\end{abstract}

Kata Kunci: implementasi kebijakan, penataan indekos, rumah kontrakan.

\begin{abstract}
The research aims to determine the implementation of the policy for structuring boarding houses or rented houses in Sukabumi City, as well as the factors that influence it. Researchers use the theory of public policy implementation according to van Metter \& van Horn. This research uses the descriptive qualitative method by collecting data through observation, interview, documentation, and literature study techniques. The implementation of the structuring policy for boarding houses or rented houses in Sukabumi City has been running well when viewed in terms of resources, characteristics of implementing agencies, and propensity/dispositions of the implementers. However, in terms of size and policy objectives, communication between organizations and implementing activities as well as the economic, social and political environment has not gone well. This is what hinders the success of the implementation of the policy on structuring boarding houses or rented houses in the City of Sukabumi.
\end{abstract}

Keywords: policy implementation, the arrangement of boarding houses, rented house. 


\section{A. PENDAHULUAN}

Berdasarkan Peraturan Daerah Kota Sukabumi Nomor 8 Tahun 2017 tentang Penataan Indekos atau Rumah Kontrakan di Kota Sukabumi, tempat indekos atau rumah kontrakan adalah tempat tinggal sementara dengan sistem pembayaran sewa berdasarkan kesepakatan antara pemilik dan/atau pengelola dengan penghuni. Banyaknya pendatang atau perantau yang berniat mengadu nasib dan melanjutkan pendidikan di Kota Sukabumi, menjadikan usaha rumah indekos atau rumah kontrakan menjadi salah satu usaha yang paling diminati. Pendatang yang berniat bekerja atau menempuh pendidikan di Kota Sukabumi tentunya sangat terbantu dengan adanya rumah indekos.

Terdapatnya fasilitas serta sarana yang memadai dibandingkan beberapa daerah di kawasan perbatasan Kota Sukabumi, membuat Kota Sukabumi menjadi pilihan utama bagi para pendatang yang ingin menetap untuk mencari kerja atau melanjutkan pendidikan. Kawasan perbelanjaan dan tempat-tempat hiburan yang ada di pusat kota juga menjadi faktor yang membuat beberapa orang menentukan Kota Sukabumi sebagai kota tujuan.

Berikut ini disajikan jumlah data rumah indekos yang ada di Kota Sukabumi:

Tabel 1 Data Rumah Indekos atau Rumah Kontrakan di Kota Sukabumi

\begin{tabular}{|c|c|c|c|}
\hline No & Kecamatan & Jumlah Kelurahan & Jumlah Indekos \\
\hline 1 & Baros & 4 & 54 \\
\hline 2 & Cibereum & 4 & 38 \\
\hline 3 & Cikole & 6 & 174 \\
\hline 4 & Citamiang & 5 & 115 \\
\hline 5 & Gunungpuyuh & 4 & 106 \\
\hline 6 & Lembursitu & 5 & 67 \\
\hline 7 & Warudoyong & 5 & 91 \\
\hline & Jumlah & 33 & 645 \\
\hline
\end{tabular}

Sumber: Penelitian (2019)

Jumlah data rumah indekos di Kota Sukabumi yaitu sebanyak 645, yang terbagi dalam 7 kecamatan yaitu Kecamatan Baros, Cibereum, Cikole, Citamiang, Gunung puyuh, Lembursitu, Warudoyong. Rumah indekos yang ada ditengah-tengah masyarakat tentunya akan berpengaruh besar bagi lingkungan sekitarnya. Seiring bertambahnya penduduk di Kota Sukabumi, sering kali orang-orang yang mencari tempat indekos mengalami kendala. Selain itu pencari tempat indekos adalah mayoritas orang-orang yang baru pindah ke Kota Sukabumi yang belum mengenal wilayah di kota Sukabumi.

Sementara itu disisi lain, Pemerintah Daerah mempunyai tugas untuk menciptakan ketentraman dan ketertiban ditengah masyarakat yang tertuang dalam Undang-Undang Nomor 23 Tahun 2014 Tentang Pemerintahan Daerah pada Pasal 65. Tentu dengan JURNAL PAPATUNG: Vol. 2 No. 3 Tahun 2019 
menjamurnya rumah indekos, pemerintah harus memperhatikan amanat dari Undang-Undang Nomor 23 Tahun 2014 tersebut. Pemerintah harus mengawasi keberadaan rumah indekos jangan sampai tidak terpelihara ketentraman dan ketertibannya.

Akhir-akhir ini sering terjadi tindak kejahatan yang terkait dengan rumah indekos. Seperti yang terjadi di salah satu Rumah Kost di Gg. Surya RT 01/04, Kelurahan Nyomplong Kecamatan Warudoyong, Kota Sukabumi. Polisi mengamankan 2 orang tersangka US (40 Tahun) dan WS alias P (42 Tahun) yang menjalankan akun twitter@sukabumiasyik. Akun twitter ini merupakan akses prostitusi online. Tersangka membagikan foto para PSK dengan mencantumkan harga dan nomor telepon, selanjutnya rumah kost tersebut dijadikan meeting point antara konsumen dan perempuan yang ditawarkan kedua pelaku via online.

Selain itu kejadian yang lain terjadi pada saat operasi yustisi, Dinas Satuan Polisi Pamong Praja Kota Sukabumi mengamankan empat pasangan bukan suami-istri di sejumlah tempat berbeda. Data dari Dinas Satuan Polisi Pamong Praja Kota Sukabumi menyebutkan operasi yustisi tersebut dilakukan disejumlah titik berbeda yakni Jalan Benteng, Jalan Sudirman, Jalan R. E. Martadinata, Gg. Ajid, Gg. Adirja, Jalan Perana, Jalan Lingkar Selatan. Selain itu Jalan lembur situ, Jalan Otista, dan Jalan Ahmad Yani.

Kejadian tersebut bertentangan dengan Peraturan Daerah Nomor 8 Tahun 2017 tentang Penataan Tempat Indekos atau Rumah Kontrakan Pasal 9 ayat 2 yang menyebutkan bahwa: Penghuni dilarang membawa tamu yang berlainan jenis kelamin ke dalam kamar tidur; membuat kegaduhan dan keonaran dalam lingkungan Tempat Indekos atau Rumah Kontrakan; meminjamkan atau menyewakan tempat indekos atau rumah kontrakan tanpa sepengetahuan pemilik dan/atau pengelola; melakukan perbuatan tercela di Tempat Indekos atau Rumah Kontrakan; dan melakukan kegiatan yang berhubungan dengan terorisme.

Terjadinya tindak kejahatan yang berkaitan dengan rumah indekos tentunya suatu dampak dari tidak ditegakkannya peraturan daerah mengenai pengelolaan indekos, karena jika hal ini ditegakkan jelas bahwa ada pihak pengelolaa yang akan dengan teliti mengecek dan menjaga ketentraman indekos yang menjadi tanggung jawab pengelolaannya. Penyimpangan-penyimpangan dalam indekos pun akan sangat sulit terjadi kecuali jika memang pihak pengelola juga ikut membantu pelaku tersebut.

Dalam pelaksanaan peraturan daerah Kota Sukabumi tentang penataan indekos dan rumah kontrakan di Kota Sukabumi, meskipun pemerintah daerah telah melaksanakan program ini tersebut dengan semaksimal mungkin, tetapi berdasarkan observasi awal yang 
peneliti dapatkan di lapangan dan berdasarkan wawancara awal yang peneliti lakukan, fenomena yang dilihat oleh peneliti yaitu:

1. Ukuran dan tujuan kebijakan

Dengan diterbitkannya peraturan daerah yang mengatur tentang penataan Indekos dan Rumah Kontrakan yang mencakup kewajiban dan larangan pemilik Indekos dan Rumah Kontrakan dengan tujuan agar lebih tertib dan tentram, namun dalam kenyataan nya masih ada penyimpangan di dalam lingkungan indekos dan pelaksanaannya masih jauh dari tujuan kebijakan tersebut dan kurang tersosialisasikan peraturan daerah ini kepada masyarakat yang ada sehingga pemilik rumah indekos atau rumah kontrakan belum mengetahui peraturan tersebut.

2. Karakteristik agen pelaksana

Sikap implementor terhadap organisasi formal dan informal yang terkait dalam implementasi kebijakan ini masih kurang efektif. Dalam penataan indekos, sikap pelaksana kebijakan atau implementor kurang baik. Hal ini dilihat dari agen pelaksana yang kurang berperan serta terhadap pemantauan kegiatan yang ada di dalam indekos. Seperti sosialisasi atau razia jarang di agendakan oleh pihak yang terkait, karena pihak terkait melaksanakan razia apabila ada laporan dari masyarakat saja.

3. Sikap dan kecenderungan

Sikap pelaksana kebijakan dilapangan sangat memprihatinkan, kaitan dengan bagaimana upaya yang dilakukan dinas terkait dalam proses penindakan, ada pertemuan yang terjadwal antara Dinas Satuan Polisi Pamong Praja dan RT setempat tapi nyata nya belum terlaksana, masih banyak RT/RW yang belum mengetahui sosialisasi yang diberikan Dinas Satuan Polisi Pamong Praja kepada RT/RW.

4. Komunikasi Antar-Organisasi dan Aktifitas Pelaksana

Komunikasi Antar-Organisasi Dinas Satuan Polisi Pamong Praja dan RT/RW masih kurang, karena perangkat desa yang berperan membantu ketentraman dan ketertiban di wilayahnya sangat jarang berkordinasi dengan Dinas Satuan Polisi Pamong Praja Sukabumi setempat ketika terjadi kejanggalan atau penyimpangan-penyimpangan yang terjadi di dalam Indekos dan Rumah Kontrakan. 
5. Lingkungan Ekonomi,Sosial, dan Politik

Masyarakat sekitar dan pemilik rumah indekos tidak memperhatikan aktivitasaktivitas di tempat indekos sehingga terjadi penyimpangan, hanya karena yang dibutuhkan pemilik indekos dan rumah kontrakan sebatas uang saja.

Tujuan penelitian ini adalah untuk mengetahui implementasi kebijakan penataan indekos atau rumah kontrakan di Kota Sukabumi, serta untuk mengetahui faktor pengahambat dan faktor pendukung keberhasilan implementasi kebijakan penataan indekos atau rumah kontrakan di Kota Sukabumi.

\section{B. KAJIAN PUSTAKA}

Dye dalam Tahir (2015), menyatakan bahwa: "Public policy is what ever governments choose to do or not to do". Konsep ini menjelaskan bahwa kebijakan publik adalah apapun yang dipilih oleh pemerintah untuk dilakukan atau tidak dilakukan. Menurutnya, apabila pemerintah memilih untuk melakukan sesuatu maka harus ada tujuan dan kebijakan negara tersebut harus meliputi semua tindakan pemerintah, bukan semata-mata pernyataan keinginan pemerintah atau pejabatnya. Disamping itu sesuatu yang tidak dilaksanakan oleh pemerintah pun termasuk kebijakan negara. Hal ini disebabkan "sesuatu yang tidak dilakukan" oleh pemerintah akan mempunyai pengaruh yang sama besarnya dengan "sesuatu yang dilakukan oleh pemerintah".

Menurut Anderson dalam Subarsono (2005), memberikan definisi kebijakan publik sebagai kebijakan-kebijakan yang dibangun oleh badan-badan dan pejabat-pejabat pemerintah. Kebijakan publik dipahami sebagai kebijakan yang buat oleh badan-badan pemerintah dan para aktor politik yang bertujuan untuk menyelesaikan masalah publik.

Sedangkan dan Plano Chandler dalam Tangkilisan (2003), berpendapat bahwa kebijakan publik adalah pemanfaatan yang strategis terhadap sumber daya-sumber daya yang ada untuk memecahkan masalah-masalah publik atau pemerintah. Dalam kenyataannya, kebijakan tersebut telah banyak membantu para pelaksana pada tingkat birokrasi pemerintah maupun para politisi untuk memecahkan masalah-masalah publik. Selanjutnya dikatakan bahwa kebijakan publik merupakan suatu bentuk intervensi yang dilakukan secara terus menerus oleh pemerintah demi kepentingan kelompok yang kurang beruntung dalam masyarakat agar mereka dapat hidup dan ikut berpartisipasi dalam pembangunan secara luas. 
Donald van Metter \& Carl van Horn dalam Agustino (2008), mengembangkan model pendekatan top down disebut dengan istilah A Model of The Policy Implementation. Proses implementasi ini merupakan sebuah abstraksi atau performansi dari suatu pelaksanaan kebijakan yang pada dasarnya secara sengaja dilakukan untuk meraih kinerja implementasi kebijakan publik yang tinggi yang berlangsung dalam hubungan dengan berbagai variabel. Model ini mengandaikan bahwa implementasi kebijakan berjalan secara liner dari keputusan politik yang tersedia, pelaksana, dan kinerja kebijakan publik.

Ada 6 (enam) variabel yang mempengaruhi kinerja implementasi kebijakan publik:

1. Ukuran dan tujuan kebijakan

Kinerja implementasi kebijakan dapat diukur tingkat keberhasilannya dari ukuran dan tujuan kebijakan yang bersifat realistis dengan sosio-kultur yang ada ditingkat pelaksana kebijakan.

2. Sumber Daya

Keberhasilan proses implementasi kebijakan sangat tergantung dari kemampuan memanfaatkan sumber daya yang tersedia. Manusia merupakan sumber daya yang terpenting dalam menentukan suatu keberhasilan proses implementasi.

Tahap-tahap tertentu dari keseluruhan proses implementasi menuntut adanya sumber daya manusia yang berkualitas sesuai dengan pekerjaan yang diisyaratkan oleh kebijakan yang telah ditetapkan secara apolitik. Tetapi ketika kompetensi dan kapabilitas dari sumber-sumber daya itu nihil, maka kinerja kebijakan publik sangan sulit untuk diterapkan.

Tetapi diluar sumber daya manusia, sumber daya lain yang perlu diperhitungkan juga ialah sumber daya finansial dan sumber daya waktu. Ini karena mau tidak mau ketika sumber daya manusia yang kompeten dan kapabel telah tersedia sedangkan kucuran dana melalui anggaran tidak tersedia, maka akan timbul masalah untuk merealisasikan apa yang hendak dituju oleh tujuan kebijakan. Demikian pula halnya dengan sumber daya waktu. Saat sumber daya manusia giat bekerja dan kucuran dana berjalan dengan baik, tetapi terbentur dengan masalah waktu yang terlalu ketat, maka hal ini pun dapat menjadi penyebab ketidakberhasilan suatu implementasi kebijkan.

3. Karakteristik agen pelaksana

Pusat perhatian pada agen pelaksana meliputi organisasi formal dan organisasi informal yang akan terlibat pengimplementasian kebijakan publik. Hal ini sangat 
penting karena kinerja implementasi kebijakan akan sangat banyak dipengaruhi oleh ciri-ciri yang tepat serta cocok dengan agen pelaksanaannya.

4. Sikap dan kecenderungan (disposition) para pelaksana

Sikap penerimaan atau penolakan dari (agen) pelaksana akan sangat banyak mempengaruhi keberhasilan atau tidaknya kinerja impelementasi kebijakan publik hal ini sangat mungkin terjadi oleh karena kebijakan publik yang dilaksanakan bukanlah hasil formulasi warga setempat yang mengenal betul persoalan yang mereka rasakan.

5. Komunikasi Antar-Organisasi dan Aktifitas Pelaksana

Koordinasi merupakan mekanisme sekaligus syarat utama dalam pembentukan keberhasilan pelaksanaan kebijakan. Semakin baik kordinasi dan komunikasi diantara pihak-pihak yang terlibat dalam suatuproses implementasi, maka asumsi kesalahan akan sangat kecil terjadi dan begitu pula sebaiknya.

6. Lingkungan Ekonomi,Sosial, dan Politik

Hal yang juga perlu diperhatikan guna menilai kinerja implementasi publik adalah sejauh mana lingkungan eksternal turut mendorong keberhasilan kebijakan publik yang telah ditetapkan.

\section{METODE PENELITIAN}

Metode penelitian yang digunakan dalam peelitian ini adalah metode deskriptif dengan pendekatan kualitatif yang diarahkan untuk memberikan gelaja, fakta-fakta, atau kejadian-kejadian secara sistematis dan akurat/mengenai sifat-sifat populasi atau daerah tertentu (Zuriah, 2006). Dengan menggunakan desain penelitian deskriptif dengan pendekatan kualitatif bertujuan untuk menggali mengenai fakta implementasi kebijakan Penataan Indekos dan Rumah Kontrakan di Kota Sukabumi.

Fokus penelitian ini mendeskripsikan implementasi kebijakan penataan indekos atau rumah kontrakan di Kota Sukabumi dengan model implementasi kebijakan van Meter \& van Horn yang meliputi dimensi ukuran dan tujuan kebijakan; sumber daya; karakteristik agen pelaksana; sikap dan kecenderungan (disposition) para pelaksana; komunikasi antarorganisasi dan aktifitas pelaksana; dan lingkungan ekonomi, sosial, dan politik.

Subyek dari penelitian ini adalah orang- orang yang dianggap mengetahui dan memahami hal-hal terkait dengan fokus penelitian, sehingga mampu memberikan informasi yang diperlukan. Penentuan informan dalam penelitian ini menggunakan menggunakan 
teknik purposive, yaitu teknik pengambilan sumber data dengan pertimbangan tertentu. Teknik pengumpulan data dilakukan melakui observasi, wawancara dan dokumentasi. Analisis data yang digunakan berupa reduksi data, penyajian data dan penarikan kesimpulan.

\section{HASIL DAN PEMBAHASAN}

Menurut van Metter dan van Horn ada enam variabel dalam kebijakan publik yaitu ukuran dan tujuan kebijakan, sumberdaya, karakteristik, agen pelaksana, sikap kecenderungan para pelaksana, komunikasi antar organisasi dan aktivitas pelaksana, serta lingkungan ekonomi sosial dan politik. Keenam factor itu peneliti gunakan untuk mengetahui bagaimana implementasi kebijakan penataan indekos atau rumah kontrakan di Kota Sukabumi.

\section{Ukuran dan tujuan kebijakan}

Kinerja implementasi kebijakan dapat diukur tingkat keberhasilannya dari ukuran dan tujuan kebijakan yang bersifat realistis dengan sosio-kultur yang ada ditingkat pelaksana kebijakan. Tujuan diadakannya kebijakan penataan indekos atau rumah kontrakan, tentunya sebagai acuan dalam mewujudkan ketentraman, ketertiban, perlindungan masyarakat daerah. Dalam Pasal 3 Peraturan Daerah Kota Sukabumi No. 8 Tahun 2017. Untuk mengetahui lebih lanjut mengenai sejauh mana tujuan dari kebijakan tersebut.

Ukuran dan tujuan kebijakan penataan indekos atau rumah kontrakan belum diketahui oleh informan dalam hal ini selaku sasaran kebijakan, Kurangnya pengetahuan mengenai Perda Penataan Indekos atau Rumah Kontrakan disebabkan kurangnya sosialisasi. Selain daripada itu masih banyaknya penyimpangan-penyimpangan yang dilakukan dalam indekos. Karena indikator-indikator menilai sejauh mana ukuran-ukuran dasar dan tujuan-tujuan dari suatu kebijakan yang telah dilaksanakan tidak akan berhasil jika tujuan dan sasaran kebijakan tidak di pertimbangkan.

Implementasi akan berjalan baik apabila ukuran-ukuran dan tujuan-tujuan dipahami oleh individu yang bertanggungjawab didalam kinerja kebijakan sesuai dengan teori yang dikemukakan oleh Van Metter dan Van Horn. Oleh sebab itu sangat penting untuk memberikan perhatian yang lebih pada kejelasan ukuran-ukuran dasar dan tujuan-tujuan kebijakan. Menurut Van Metter dan Van Horn implementor mungkin bisa jadi gagal dalam melaksanakan kebijakan, karena mereka menolak atau tidak mengerti apa yang menjadi tujuan suatu kebijakan. Jika dilihat dari teori Van Metter dan Van Horn, kebijakan penataan indekos atau rumah kontrakan dinilai gagal dalam pengimplementasiannya, karena sasaran kebijakan yaitu pemilik indekos, penghuni indekos, RT/RW, masyarakat setempat tidak 
mengerti bahkan tidak mengetahui isi dari kebijakan tersebut. Seharusnya kebijakan tersebut disosialisasikan kepada pemilik indekos, penghuni indekos, dan RT/RW setiap 1 (satu) tahun sekali agar sasaran kebijakan mengetahui isi dari kebijakan tersebut. Dengan demikian, tujuan kebijakan penataan indekos atau rumah kontrakan dapat berhasil dilaksanakan.

\section{Sumber Daya}

Keberhasilan proses implementasi kebijakan sangat tergantung dari kemampuan memanfaatkan sumber daya yang tersedia. Manusia merupakan sumberdaya yang terpenting dalam menentukan keberhasilan suatu implementasi kebijakan. Setiap tahap implementasi menuntut adanya sumber daya manusia yang berkualitas. Sumber daya aparatur yang dimiliki oleh Polisi Pamong Praja dalam pelaksanaan kebijakan itu sudah cukup baik. Berdasarkan data yang diperoleh di kantor Polisi Pamong Praja jumlah aparat yang diterjunkan pada setiap razia indekos yaitu sejumlah 40 anggota POL PP dibagi dua tim dan setiap tim beroperasi di lima lokasi. Selain dari Polisi Pamong Praja, TNI dan Polisi pun ikut andil dalam penataan indekos yakni hanya berlaku sebagai pendampingan. Ketika terjadi masalah yang tidak bisa ditangani langsung oleh Polisi Pamong Praja. Contohnya apabila penghuni indekos tersebut aparat atau masyarakat biasa yang sulit untuk diajak komunikasi, terkadang pihak Polisi Pamong Praja mengalami kesulitan untuk menindak. Karena penghuni tersebut merasa lebih tinggi jabatannya dengan Polisi Pamong Praja. Dalam kondisi tersebut, Polisi Pamong Praja meminta bantuan kepada pihak polisi dan TNI.

Menurut Van Metter dan Van Horn mengemukakan bahwa sumber daya memiliki peranan yang besar dalam mempengaruhi keberhasilan pencapaian suatu tujuan organisasi. Keberhasilan proses implementasi kebijakan sangat tergantung dari kemampuan memanfaatkan sumber daya yang tersedia. Manusia merupakan sumber daya yang terpenting dalam menentukan suatu keberhasilan proses implementasi. Dalam hal ini sumber daya aparatur yang dimiliki oleh Polisi Pamong Praja dalam pelaksanaan kebijakan itu sudah cukup baik. Dengan bantuan TNI dan Polisi yang ikut andil dalam penataan indekos.

Dalam pandangan George Edwards III (Subarsono, 2013: 90), Sumber daya sangatlah penting keberadaannya jika implementor kekurangan sumber daya untuk pelaksanaan maka implementasi tidak akan berjalan efektif. Sumberdaya dapat berupa manusia dan sumberdaya finansial. Maka dari itu, implementasi kebijakan penataan indekos atau rumah kontrakan akan berhasil apabila seluruh aparat Polisi Pamong Praja, TNI, dan Polisi berintegrasi dalam pengimplementasiannya.

3. Karakteristik Agen Pelaksana 
Pusat perhatian pada agen pelaksana meliputi organisasi formal dan organisasi informal yang akan terlibat dalam pengimplementasian kebijakan. Hal ini penting karena kinerja implementasi kebijakan akan sangat dipengaruhi oleh ciri yang tepat serta cocok dengan para agen pelaksana. Hal ini berkaitan dengan konteks kebijakan yang akan dilaksanakan pada beberapa kebijakan dituntut pelaksana kebijakan, pada konteks ini diperlukan agen pelaksana yang demokratis.

Sasaran kebijakan yaitu pemilik dan penghuni indekos serta RT/RW setempat merasakan bahwa karakteristik agen implementor sudah baik, hal tersebut bisa dilihat dari informan-informan yang menanggapi karakteristik dari implementor dengan tanggapan baik. Dalam suatu implementasi kebijakan, agar mencapai keberhasilan maksimal harus diidentifikasikan dan diketahui karakteristik agen pelaksana yang mencakup struktur birokrasi, norma-norma, dan pola-pola hubungan yang terjadi dalam birokrasi, semua itu akan mempengaruhi implementasi suatu program kebijakan yang telah ditentukan.

Pusat perhatian pada agen pelaksana meliputi organisasi formal dan organisasi informal yang akan terlibat dalam pengimplementasian kebijakan publik, apabila dilihat dari teori tersebut, dapat diinterpretasikan bahwa perhatian dari para agen pelaksana terhadap sasaran kebijakan terasa baik.

\section{Sikap dan kecenderungan (disposition) para pelaksana}

Sikap penerimaan atau penolakan dari (agen) pelaksana akan sangat banyak mempengaruhi keberhasilan atau tidaknya kinerja impelementasi kebijakan publik. Berhasil atau tidaknya suatu kebijakan berkaitan dengan sikap atau kecenderungan (disposition) para pelaksana, penerimaan atau penolakan dari agen pelaksana akan sangat mempengaruhi kebijakan yang akan implementor laksanakan. sikap dari pelaksana penataan indekos atau rumah kontrakan di Kota Sukabumi dapat dikatakan sudah optimal dan dikatakan baik. Hal ini dapat dibuktikan dengan ketegasan Polisi Pamong Praja dalam menjalankan peraturan daerah penataan indekos atau rumah kontrakan, dengan tidak melupakan etika kesopanan.

Implementasi kebijakan akan terlaksana dengan baik jika semua pihak memberi dukungan terhadap kebijakan, bila tingkah laku atau perspektif mereka berlawanan maka proses pelaksanaan kebijakan akan semakin sulit. Karena menurut Van Metter dan Van Horn, intensitas kecenderungan-kecenderungan pelaksana akan mempengaruhi kinerja kebijakan itu sendiri. Sikap penerimaan atau penolakan dari (agen) pelaksana akan sangat banyak mempengaruhi keberhasilan atau tidaknya kinerja impelementasi kebijakan publik hal ini 
sangat mungkin terjadi oleh karena kebijakan publik yang dilaksanakan bukanlah hasil formulasi warga setempat yang mengenal betul persoalan yang mereka rasakan.

Van Mater dan Van Horn (1974) dalam (Agustino, 2006) menjelaskan disposisi bahwa implementasi kebijakan diawali penyaringan (befiltered) lebih dahulu melalui persepsi dari pelaksana (implementors) dalam batas mana kebijakan itu dilaksanakan. Terdapat tiga macam elemen respon yang dapat mempengaruhi kemampuan dan kemauannya untuk melaksanakan suatu kebijakan, antara lain terdiri dari pertama, pengetahuan (cognition), pemahaman dan pendalaman (comprehension and understanding) terhadap kebijakan, kedua, arah respon mereka apakah menerima, netral atau menolak (acceptance, neutrality, and rejection), dan ketiga, intensitas terhadap kebijakan.

Pemahaman tentang maksud umum dari suatu standar dan tujuan kebijakan adalah penting. Karena, bagaimanapun juga implementasi kebijakan yang berhasil, bisa jadi gagal ketika para pelaksana dalam hal ini Polisi Pamong Praja, tidak sepenuhnya menyadari terhadap standar dan tujuan kebijakan. Arah disposisi para pelaksana (implementors) terhadap standar dan tujuan kebijakan juga merupakan hal yang "crucial". Implementors mungkin bisa jadi gagal dalam melaksanakan kebijakan, dikarenakan mereka menolak apa yang menjadi tujuan suatu kebijakan.

Sebaliknya, penerimaan yang menyebar dan mendalam terhadap standar dan tujuan kebijakan diantara mereka yang bertanggung jawab untuk melaksanakan kebijakan tersebut, adalah merupakan suatu potensi yang besar terhadap keberhasilan implementasi kebijakan. Pada akhirnya, intesitas disposisi para pelaksana (implementors) dapat mempengaruhi pelaksana (performance) kebijakan. Kurangnya atau terbatasnya intensitas disposisi ini, akan bisa menyebabkan gagalnya implementasi kebijakan. Namun, dalam hal ini Polisi Pamong Praja sebagai pelaksana dari Kebijakan Penataan Indekos atau Rumah Kontrakan dinilai berhasil dalam pelaksanaanya. Dikarenakan sikap penerimaan dari tujuan suatu kebijakan Penataan Indekos atau Rumah Kontrakan.

5. Komunikasi Antar-Organisasi dan Aktifitas Pelaksana

Komunikasi merupakan mekanisme sekaligus syarat utama dalam pembentukan keberhasilan pelaksanaan kebijakan. Semakin baik koordinasi dan komunikasi diantara pihak-pihak yang terlibat dalam suatu proses implementasi, maka asumsi kesalahankesalahan akan sangat kecil terjadi dan begitu pula sebaliknya. Faktor komunikasi sangat berperan penting bagi pelaksana kebijakan penataan indekos atau rumah kontrakan, 
komunikasi juga termasuk sarana memberi informasi dan interaksi antara yang satu dengan yang lain.

Suatu implementasi yang efektif akan terlaksana dengan baik, jika para pembuatan keputusan mengetahui apa yang mereka kerjakan. Komunikasi pula merupakan salah satu variabel yang mempengaruhi impelementasi kebijakan publik, komunikasi sangat menentukan keberhasilan pencapaian tujuan dari implementasi kebijakan publik. Miskomunikasi sering terjadi mengenai hak-hak, kewajiban dan larangan pemilik/pengelola dan penghuni, dikarenakan pemilik/pengelola dan penghuni belum mengetahuinya. Dalam mengimplementasikan kebijakan penataan indekos atau rumah kontrakan komunikasi yang dilakukan belum terjalin dengan baik.

Hal tersebut disebabkan oleh kurangnya koordinasi mengenai peraturan penataan indekos/rumah kontrakan yang mengakibatkan timbulnya beberapa permasalahan yang sudah dijelaskan diatas dan akan menyulitkan para pelaksana kebijakan karena konsistensi yang tidak sesuai dengan adanya ukuran-ukuran dasar dan tujuan-tujuan.

6. Lingkungan Ekonomi, Sosial, dan Politik

Hal yang juga perlu diperhatikan guna menilai kinerja implementasi publik adalah sejauh mana lingkungan eksternal turut mendorong keberhasilan kebijakan publik yang telah ditetapkan. Faktor lingkungan ekonomi, sosial dan politik menjadi salah satu factor penting dalam berjalannya suatu implementasi kebijakan. Jika lingkungan tidak mendukung maka dapat menjadi inti dari kegagalan suatu inplementasi kebijakan. lingkungan ekonomi, sosial dan politik dalam penataan indekos atau rumah kontrakan belum optimal, hal ini di lihat dari lingkungan sosial dan ekonomi, kurangnya partisipasi masyarakat kepada aktivitas di dalam indekos. Namun apabila dilihat dari lingkungan ekonomi ternyata pemilik hanya membutuhkan sebatas uang saja, tanpa memperhatikan aktivitas yang ada di dalam indekos.

Hal yang juga perlu diperhatikan guna menilai kinerja implementasi publik adalah sejauh mana lingkungan eksternal turut mendorong keberhasilan kebijakan publik yang telah ditetapkan, apabila dilihat dari sudut pandang teori, dimensi ini masih belum optimal, dikarenakan lingkungan sosial, ekonomi dan masih ada yang menjadi faktor penghambat kebijakan. Kondisi ekonomi, sosial dan politik merupakan variabel selanjutnya yang diidentifikasi oleh Van Meter van Horn. Dampak pada kebijakan publik merupakan pusat perhatian yang besar selama dasawarsa yang lalu. Para peminat perbandingan politik dan kebijakan publik secara khusus tertarik dalam mengidentifikasikan pengaruh variabel lingkungan pada hasil kebijakan. Sekalipun dampak dari faktor-faktor ini pada implementasi 
keputusan kebijakan mendapat perhatian yang kecil, namun faktor ini mungkin mempunyai efek yang mendalam terhadap pencapaian badan-badan pelaksana.

Variabel kondisi lingkungan mempunyai pengaruh yang penting pada keinginan dan kemapuan yuridiski atau organisasi pelaksana. Lingkungan eksternal dalam hal ini lingkungan Ekonomi Sosial dan Politik turut mendorong keberhasilan kebijakan publik khusunya Penataan Indekos atau Rumah Kontrakann, peneliti berintrepretasi bahwa kurangnya partisipasi masyarakat kepada aktivitas di dalam indekos.

Dalam hal ini, dari segi ekonomi pemilik hanya membutuhkan sebatas uang saja, tanpa memperhatikan aktivitas yang ada di dalam indekos. Terkait sosial masih kurangnya partisipasi masyarakat kepada aktivitas di dalam indekos. Dan keterlibatan politik memang tidak dapat dipungkiri keberadaanya, mulai perizinan, pendataan kependudukan, tingkat keamanan yang perlu diperhatikan oleh seluruh pelaksana kebijakan.

\section{E. KESIMPULAN}

Berdasarkan hasil penelitian mengenai implementasi kebijakan penataan indekos atau rumah kontrakan di Kota Sukabumi dengan menggunakan teori Donald Van Metter dan Carl Van Horn dapat disimpulkan bahwa, pertama, ukuran dan tujuan kebijakan penataan indekos atau rumah kontrakan belum diketahui oleh informan dalam hal ini selaku sasaran kebijakan, kurangnya pengetahuan mengenai perda penataan indekos atau rumah kontrakan disebabkan kurangnya sosialisasi. Kedua, sumber daya aparatur yang dimiliki oleh Polisi Pamong Praja dalam pelaksanaan kebijakan penataan indekos atau rumah kontrakan sudah cukup baik. Selain dari Polisi Pamong Praja, TNI dan Polisi pun ikut andil dalam penataan indekos yakni hanya berlaku sebagai pendampingan. Ketiga, sasaran kebijakan merasakan bahwa karakteristik agen implementor sudah baik. Apabila dilihat dari Peraturan Daerah Kota Sukabumi No. 8 Tahun 2017, karakteristik dari implementor dirasa sudah berjalan dengan baik, hal tersebut bisa dilihat dari informan-informan yang menanggapi karakteristik dari implementor dengan tanggapan baik. Keempat, sikap dari pelaksana penataan indekos atau rumah kontrakan di Kota Sukabumi dapat dikatakan sudah optimal dan dikatakan baik. Hal ini dapat dibuktikan dengan ketegasan Polisi Pamong Praja dalam menjalankan peraturan daerah penataan indekos atau rumah kontrakan, dengan tidak melupakan etika kesopanan. Kelima, komunikasi yang dilaksanakan belum efektif antara pelaksana kebijakan dan sasaran kebijakan. Dalam mengimplementasikan kebijakan penataan indekos atau rumah kontrakan komunikasi yang dilakukan belum terjalin dengan baik hal ini dapat dilihat dari jawaban 
informan yang mengutarakan bahwa tidak pernah terjalin komunikasi antara pihak RT/RW dengan Polisi Pamong Praja. Keenam, Lingkungan ekonomi, sosial dan politik dalam penataan indekos atau rumah kontrakan belum optimal. Hal ini di lihat dari lingkungan sosial dan ekonomi, kurangnya partisipasi masyarakat kepada aktivitas di dalam indekos. Namun apabila dilihat dari lingkungan ekonomi ternyata pemilik hanya membutuhkan sebatas uang saja, tanpa memperhatikan aktivitas yang ada di dalam indekos.

Faktor penghambat dalam implementasi kebijakan penataan indekos atau rumah kontrakan adalah (1) ukuran dan tujuan kebijakan, (2) komunikasi antar-organisasi dan aktivitas pelaksana, (3) lingkungan sosial, ekonomi dan politik. Faktor pendukung dalam implementasi kebijakan penataan indekos atau rumah kontrakan adalah (1) sumber daya, (2) karakteristik agen pelaksana, dan (3) sikap dan kecenderingan (disposition) para pelaksana.

\section{DAFTAR PUSTAKA}

Afrizal. (2014). Metode Penelitian Kualitatif. Jakarta: PT. Raja Grafindo Persada.

Agustino. (2008). Dasar-Dasar Kebijakan Publik. Bandung: Alfabeta.

Akib, H. (2012). Implementasi kebijakan: Apa, mengapa dan bagaimana. Jurnal Ilmiah Ilmu Administrasi Publik, 1(1), 1-11.

Bungin, B. (2007). Penelitian Kualitatif: Komunikasi, Ekonomi, Kebijakan Publik dan Ilmu Sosial Lainnya. Jakarta: Putra Grafika.

Erwan, \& Sulistyastuti, D. R. (2005). Metode Penelitian Kuantitatif untuk Administrasi Publik dan Masalah-Masalah Sosial. Yogyakarta: Gava Media.

Hidayat, S. (2017). Implementasi Kebijakan Pajak Rumah Kos Kabupaten Sleman. Yogyakarta: Skripsi Universitas Negeri Yogyakarta.

Iskandar, I. (2011). Implementasi Peraturah Daerah Kota Makassar Nomor 10 Tahun 2011 Tentang Pengelolaan Rumah Kost. Makassar: Skripsi Universitas Hassanudin.

Khoiriyah, A. (2017). Analisis Pengaruh Bauran Pemasaran terhadap Pengambilan Keputusan Nasabah pada BMT Mekar Abadi Aji Sejahtera. Skripsi UIN Raden Intan Lampung

Peraturan Daerah Nomor 8 Tahun 2017 tentang Penataan Indekos atau Rumah Kontrakan di Kota Sukabumi

Permana, I. G. (2013). Tinjauan Yuridis Pengelolaan Rumah Kos Berdasarkan Peraturan Kabupaten Badung 24 Tahun 2013. Skripsi Universitas Warmadewa Bali.

Satuan Polisi Pamong Praja. (2019). Data Rumah Indekos atau Rumah Kontrakan Tahun 2019.

Subarsono. (2005). Analisis Kebijakan Publik. Yogyakarta: Pustaka Pelajar.

Sugiyono. (2008). Metode Penelitian Kualitatif dan R\&D. Bandung: Alfabeta.

Tahir, A. (2015). Kebijakan Publik \& Transparansi Penyelengaraan Pemerintahan Daerah. Bandung: Alfabeta.

Tangkilisan, H. N. S., \& Saputro, S. H. (2003). Implementasi Kebijakan Publik: Transformasi Pikiran George Edwards. Yogyakarta: Lukman Offset \& Yayasan Pembaruan Administrasi Publik Indonesia (YPAPI). 


\section{ARTIKEL}

Winarno, B. (2012). Kebijakan Publik Teori, Proses, dan Studi Kasus. Yogyakarta: CAPS.

Wirawan. (2011). Evaluasi Teori Model Standar Aplikasi dan Profesi, Contoh Aplikasi Evaluasi Program: Pengembangan Sumber Daya Manusia Program Nasional Pemberdayaan Masyarakat (PNPM) Mandiri Pedesaan, Kurikulum, Perpustakaan, dan Buku Tes. Jakarta: Raja Grafindo Persada.

Zuriah, N. (2006). Metodologi Penelitian Sosial dan Pendidikan: Teori Aplikasi.Jakarta: Bumi Aksara. 